\title{
Anmeldelse: Ruslands mafia
}

Af Mette Skak

Forfatteren Mark Galeotti er en af de førende sagkyndige på såvel de russiske efterretningstjenester som russisk organiseret kriminalitet. Det foruroligende ved hans to forskningsfelter er det symbiotiske forhold, der hersker mellem Putins russiske stat dvs. netop dens efterretningstjenester og nutidens kriminelle post-sovjetiske underverden.

\section{Mark Galeotti: The Vory. Russia's} Super Mafia. New Haven \& London: Yale University Press 2018, 326 sider.

Bogen her om 'vory' (= tyvene) kan bestemt anbefales som en på samme tid underholdende og deprimerende sociologisk analyse af den sovjetiske og post-sovjetiske organiserede kriminalitets historie.

Som Galeotti bemærker, afspejler underverdenens op- og nedture fra Lenin og Stalin frem til Bresjnev, Gorbatjov og Sovjetunionens sammenbrud den samlede sovjetiske

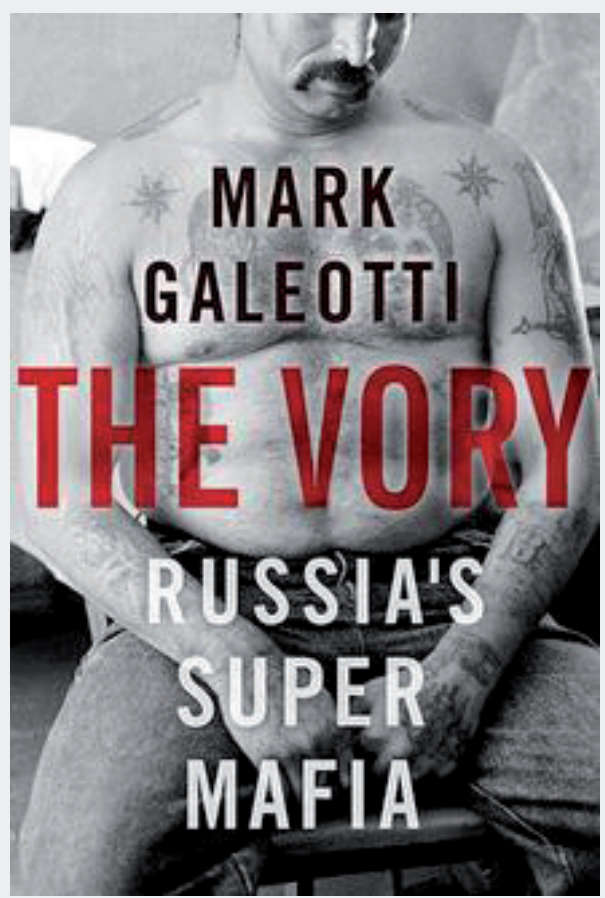

samfundsdynamik. Det næsten fuldbyrdede statskollaps under Jeltsin i 1990'erne kom tilsvarende til udtryk i vilde bandekrige og utallige blodige likvideringer. 
Putintiden er som nævnt kendetegnet ved en særegen symbiose mellem overog underverden inklusive konjunkturudsving med dønninger ud i gangstermiljøerne - dels den økonomiske krise i 2008, dels sanktionskrisen, hvad angår Ruslands forhold til Vesten fra 2014 og frem. Derfor er Hviderusland i disse år et knudepunkt for ikke bare heroin-, men også ostesmugling ind i Rusland. I 2015 blev en bande knaldet for i løbet af seks måneder at have optjent 34 mio. dollar på den fidus. Den russiske gangster Pjotr 'Banan' er en af dem, der gik over til at være 'ostegrosserer'.

\section{Den største bande i byen}

Putin-tiden kendetegnes ifølge Galeotti ved, at Kreml tolererer organiseret kriminalitet, når blot sidstnævnte loyalt udfører eventuelle ordrer fra førstnævnte og i det hele taget forstår, at 'staten er den største bande i byen'. Konkret peger Galeotti på Kremls brug af ikke bare små grønne mænd fra GRU til at besætte Krim, men også en berygtet gangster som Sergej Aksjonov, der blev premierminister på halvøen og ellers kendtes som Goblin fra Salem-banden.

Angående motiv kunne Krim-halvøens kasinoer og turisme med lidt held gøre Sevastopol til en rival til den ukrainske sortehavsby Odessa - gangsternes paradis på de kanter. I Donbas blev krigsførelsen fra russisk side gjort ekstra beskidt gennem brug af fodsoldater og officerer fra den russiske underverden, og i nutiden er storbyen Luhansk uden for selv Kremls pædagogiske rækkevidde ifølge denne anmelders kilder.
Det store problem set fra et vesteuropæisk synspunkt ved den virkelighed, som Galeotti beskriver, er, at den organiserede kriminalitet, der har støttepunkter i Rusland, dels er håndlanger for Kreml i dens kampagne for at undergrave demokratierne og sammenholdet i EU fx via dens kompetencer på feltet cyberkrigsførelse og hacking, dels er håndlanger for den øvrige europæiske kriminelle underverden fx i kraft af dens kompetencer på feltet hvidvaskning.

Med andre ord påpeger Galeotti nogle afgørende og rent ud kriminelle mekanismer bag demokratiets krise til fordel for den populistiske yderfløj. Han anbefaler en beslutsom, koordineret indsats i EU-regi som et tvingende nødvendigt forsvar mod denne hybride russiske krigsførelse. À propos Danske Bank-skandalen advarer han indtrængende mod at lukke øjnene for hvidvaskning.

Følgelig er det bogens sidste halvdel, der påkalder sig størst interesse som altafgørende indblik i, hvordan Rusland rent faktisk fungerer nu og fremover. Desværre er det her, at Galeotti i nogen grad forfalder til sløsede diagnoser og selvmodsigelser.

Et sted ophøjer han den russiske cyberkriminalitet til en autonom sfære, andetsteds gøres den til en temmelig integreret del af den kriminelle helhed, der i sidste instans har Kreml som principal. Russiske gangstere agerer gerne håndlangere for den japanske yakuza og de kinesiske triader, der ligesom russerne gerne vil gøre 'forretninger' i Ussuri-bugtens casino nær Vladivostok. 
Dog er de russiske fjernøstlige gangstere lidt i defensiven ifølge Galeotti, og man aner, at Kinas økonomiske dominans vil få yderligere følger - hvilke diskuteres desværre ikke af ham. Den gode nyhed angående Putins tid ved magten er, at rå vold begået af benbrækker-eksperter og mordere fortrænges af sindrig økonomisk kriminalitet. Fjendtlige overtagelser sker nu ved habitklædte gråzone-advokaters og ikke skydevåbens mellemkomst.

\section{Sandfærdig indføring}

Sammenlignet med de banebrydende follow the money-kortlægninger i nyligt afdøde Karen Dawishas Putin's Kleptocracy fra 2014 synes denne anmelder, at Galeotti bringer for lidt stof om Kremls egne sinistre nøgleaktører såsom Rosneft-bossen Igor Setjin, formanden for Ruslands nationale Sikkerhedsråd Nikolaj Patrusjev, chefen for Putins nye nationalgarde Rosgvardija Viktor Zolotov, Putin-rådgiveren Sergej Glazjev samt Putin selv.

Bortset fra det fortjener The Vory at blive læst som en alternativ, men desværre sandfærdig indføring i Rusland og dets sovjetiske fortid. Galeotti fører læseren grundigt ind i tyvenes normer og sprogbrug og bringer en nyttig ordliste over gangsterslang bagest, hvortil kommer hans omfattende bibliografi.

Det ubehagelige er bogens uundgåelige stof om vold, herunder det som Galeotti kalder tyvenes rædselsfulde misogyni og forhistoriske kvindesyn. Indsigten har han fra Varlam Sjalamov, der beskrev GULag indefra i kunstnerisk form. Galeotti følger op med beretningen om en kvinde blandt gangsterne, der spyttede en af dem i ansigtet som svar på en fornærmelse. Hendes gangsterkæreste tog hende ikke i forsvar, fordi han netop anså hende for et laverestående væsen og lod derfor de tilstedeværende gruppevoldtage hende.

For at vende tilbage til det omvendt kronologiske spor fortjener Galeotti ros for aflive myter om det oprørske Tjetjenien og dets magthavere. Galeotti påpeger, at Tjetjenien under den nuværende brutale og såre autonome statholder Ramzan Kadyrov har opnået mere selvstændighed end nogensinde vel at mærke på Moskvas regning. Den tjetjenske mafia uden for Tjetjenien mener han imidlertid ikke er håndlangere for Kadyrov.

Galeotti giver udbryderrepublikkens første leder Dzjokar Dudajev det glatte lag. Med ham som godfather blev Tjetjenien gangsternes sande Paradis. I løbet af et enkelt år - 1992 - fik Tjetjeniens Nationalbank svindlet et rubelbeløb svarende til 700 mio. dollar ud af Ruslands Centralbank. Den nok allermest farlige nulevende godfather ifølge Galeotti er imidlertid georgieren Tariel Oniani (Taro blandt venner), fordi han blæser på spillets regler og har ustyrlige imperiale ambitioner (s. 227).

FBI's bud på, hvem det er vigtigst at få bag lås og slå, er underverdenens egen bankier Semjon Mogiljevitj, der lever højt på den russiske forfatnings paragraf 61 . Den forbyder udlevering af russiske statsborgere til strafforfølgelse. For en sikkerheds skyld har Mogiljevitj derudover sørget for at have 
statsborgerskab i både Israel, Ukraine og Grækenland. I øvrigt svindler ikke-jødiske gangstere sig ofte til israelsk statsborgerskab.

\section{De vilde 90'ere}

De vilde 1990'ere under den fordrukne, men velmenende præsident Boris Jeltsin var årtiet, hvor den organiserede kriminalitet havde kronede røverkapitalistiske dage. Jeltsin selv udnævnte beskæmmet Rusland til kriminalitetens supermagt.

Det er denne anmelders overbevisning, at miseren i mindre grad skyldtes chokterapien, men snarere den mere og mere korrupte såkaldte socialisme i Sovjettiden, der gjorde indgreb nødvendige. I hvert fald har historikeren Stephen Kotkin gjort op med misforståelsen af periodens politiske økonomi i bogen Averting Armageddon fra 2000. Hvorom alting er, var det i 1990'erne, at hovedbyerne Moskva og Skt. Petersborg fik hver deres svøbe af gangstervælde - henholdsvis banderne Solntsevo og Tambovskaja, der naturligvis rivaliserede indbyrdes, ligesom deres to hjembyer gør det. Galeotti fremhæver derudover et mønster, der peger frem mod nutiden: visse bandelederes forfremmelse til betroede mæglere i bandeopgørene - avtoritety - og samtidig halvvejs lovlige kapitalistiske entreprenører eller foreningsstiftere, fx georgieren Otari Kvantrishvili (Otarik).

Galeotti anser Jeltsins forgænger Gorbatjov for endnu mere fatalt naiv med sin perestrojka. Sagen er vel, at KGB og partitoppen konspirerede bag hans ryg om fjernelse af partiets enor- me økonomiske aktiver, hvorved de banede vejen for putinismens symbiose mellem efterretningstjenester og organiseret kriminalitet?

\section{De glade 70'ere}

De glade, men inderligt korrupte 1970'ere indrammes med følgende tilståelse fra datidens generalsekretær for partiet, selveste Leonid Bresjnev: "Ingen lever udelukkende af deres løn. Jeg husker fra min ungdom, at vi tjente penge ved at bemoegtige os indholdet fra jernbanens godsvogne. Hvordan gjorde vi så det? Jo, hver gang, der var tre pakkasser eller postscekke, der skulle loesses af, tog vi den fjerde til os selv. Sådan lever alle i landet." (oversat fra s. 92).

Planøkonomiens systematiske svigt af den menige sovjetforbruger indbød til alskens nødløsninger og tyverier. Alle måtte ty til smøring (blat), og virksomhederne havde en særlig mellemmand (tolkatj) til at sikre forsyninger af råvarer. I Georgien dækkede den lokale partisekretær over republikkens førende gangster, hvad der endte med, at den senere kendte Sjevardnadze med KGB-chefen Andropovs opbakning måtte gribe ind $\mathrm{i}$ 1972. Den usbekiske bomuldssvindel i de tidlige 1980 'ere gik helt til tops i systemet, hvor straffen ramte Brezjnjevs svigersøn - igen på Andropovs foranledning.

Men den egentlige smeltedigel for Sovjettidens mafiøse tyvekultur - vory v zakone - var Stalins terror med GULag-lejrene som afsoningssted for mindst 28,7 mio. sovjetborgere ifølge historikeren Anne Applebaum. Her 
smeltede politiske fanger sammen med simple kriminelle og internerede forældreløse teenagere.

Nøden i lejrene animerede til at skaffe forsyninger fra det omgivende landområdes sorte marked, som det skete i en sag fra 1947 i Novosibirsk med en betroet fange som omdrejningspunkt; han blev dømt og skudt. En kollaboratør omtaltes af tyvene som en tæve og blev af og til selv myrdet. Med sovjetmagtens billigelse kom det sidst i 1940'erne og begyndelsen af 1950 'erne til et formidabelt opgør mellem kollaboratører og kriminelle, som Galeotti beskriver under overskriften 'The bitches war'. Opgøret endte med at true stabiliteten i hele GULag som straffesystem, konkluderer han.

Men først efter Stalins død i 1953 og ironisk nok med Stalins bøddel Beria som fremsynet mellemmand blev GULag-systemet droslet ned. Ifølge Berias opgørelse var kun 221.435 af GU-
Lag-fangerne farlige fjender af staten ud af sammenlagt 2.526.402 internerede - eller kun godt 11 pct. Før Stalin var der kynikeren og fanatikeren Lenin, der i 1915 satte lighedstegn mellem de rige og de småkriminelle som fjender af socialismen. Herved friholdt han de store forbrydere. Galeotti citerer førnævnte Kvantrishvili: "Det var Vladimir Iljitj Lenin, der var den egentlige organisator af mafiaen og ham, der stablede forbryderstaten på benene." (oversat fra s. 38).

Alskens udskud og voldtægtsforbrydere søgte ind i Lenins hemmelige politi Tjeka samtidig med, at den modbydelige borgerkrig 1918-1922 forråede alle. Men før den tid havde sen-zarismens spæde industrialisering og armod i storbyerne skabt rammer for gangstervældet. 